\title{
Green Criminology for Social Sciences: Introduction to the Special Issue
}

\author{
Bill McClanahan * and Avi Brisman \\ School of Justice Studies, Eastern Kentucky University, 521 Lancaster Ave, 467 Stratton, Richmond, KY 40475, \\ USA; avi.brisman@eku.edu \\ * Correspondence: bill.mcclanahan@eku.edu
}

Received: 24 September 2020; Accepted: 29 September 2020; Published: 29 September 2020

April 22, 2020 marked the 50th anniversary of Earth Day. In contrast to the first Earth Day in 1970, when millions of people took to the streets to protest air and water pollution and to demonstrate support for environmental protection (Browning 2020; Lockwood 2020), few people left their homes, let alone marched. Instead, millions were sheltering-in-place to try to retard the spread of COVID-19. But even if we were not in the midst of a global pandemic, one has to wonder how much of a celebration we could or should have held.

The immediate aftermath of Earth Day 1970 ushered in a host of environmental legislation: in the United States alone, the Clean Air Act, Clean Water Act, Endangered Species Act, Marine Mammal Protection Act, National Forest Management Act, Resource Conservation and Recovery Act and Toxic Substances Control Act were all passed with bipartisan support in the 1970s. Unfortunately, the "Environmental Decade" symbolized by the first Earth Day in the 1970s (see Tuholske 2017), did not lead to an "Environmental Semi-Centennial." Indeed, in 2020, we are bearing witness to disappearing Arctic ice, dying coral reefs, floating plastic garbage patches, floods, greenhouse gas emissions, intensifying storms, raging wildfires, a precipitous sea-level rise and searing summer heat-as well as mourning the loss of human and nonhuman life in the Deepwater Horizon explosion off the coast of Louisiana, which occurred ten years ago this April (on almost the exact day of the 40th anniversary of Earth Day) and set into motion the biggest oil spill in the history of the United States (Editorial Board 2020). And with the Trump Administration's concentrated efforts to eviscerate so many environmental measures (e.g., Bloomberg and McCarthy 2020; Popovich et al. 2020; Tollefson 2020), as well as its steadfast commitment to profits over preparedness (Editorial Board 2020), there seems little reason for hope.

We are not sanguine. But we are also not silent-and we are not alone. The articles in this Special Issue, written by an international cadre of researchers and scholars, reflect growing in an area known as "green criminology," which has sought to recast the criminological gaze onto crimes and harms affecting non-human life, ecosystems and the biosphere. The result has been an area of scholarship which has blossomed to encompass and speak to a diverse range of interests and concerns, including air and water pollution, climate change, deforestation, the extraction and metabolization of natural "resources," harms to animals other than human animals, environmental (in)justice and relationships between "nature" and "culture." Along the way, green criminology has made significant contributions to our understanding of the causes, consequences and prevalence of these environmental crimes and harms, the responses to and prevention of such environmental crimes and harms by the legal system (civil, criminal, regulatory) and by nongovernmental entities and social movements, and the meaning and mediated representations of environmental crimes and harms.

To some extent, green criminology has been slow to find its place alongside other disciplinary trends in environmental research. Green criminology, it seems, continues the tradition of self-isolation-social distancing, if one will—established by criminology writ large in its divorce from sociology. While we 
might find entire departments, funded research centers and conferences dedicated to similar disciplines like environmental sociology, green criminology has yet to find that sort of momentum or legitimacy. This is not to say, of course, that green criminology has not made significant impact and headway. Quite the contrary, in fact: the relative invisibility of environmental concerns in criminology is so glaring precisely because there has now been roughly three decades of sustained scholarship undertaken beneath the banner of green criminology with which that invisibility can be contrasted.

This Special Issue, in many ways, is a minor attempt at raising the visibility of that banner so that it might be seen across disciplinary divides. The value of interdisciplinary research is undisputed, and this seems to be the case especially when working to analyze and understand complex and multivariate ecological problems-ones that do not respect academic campsites or national borders. While green criminology might be well suited to offer some insights into, for example, the environmental outcomes of organizational or industrial deviance or criminality, the resulting analyses might also necessitate some consideration of the economic, social or political dimensions of the issue in order to paint an adequately vivid picture. While green criminologists, of course, each have their own unique interests and areas of focus, which might buttress or lead to such an analysis, it remains the case that multivariate problems require multipronged analyses, and we find again and again that green criminology has at its core precisely those tendencies.

In the spirit of fostering the sort of disciplinary cross-pollination that we imagine might enliven and invigorate criminological debates and conversations surrounding environmental harm and crime, this Special Issue proceeds without a more specific thematic thread with which to bind the articles, other than the type of concern expressed at the outset. Instead, recognizing the broad audience of a journal like Social Sciences—which speaks across disciplinary and geographic cleavages-our aim in assembling this issue has been, largely, to expose new audiences to a collection of new and compelling papers which are, we feel, representative of the diversity within green criminology.

We begin, perhaps fittingly, with one of the most essential elements of both biotic human life and constructed human cultures: food. In this first article, "Food Crime: A Review of the UK Institutional Perception of Illicit Practices in the Food Sector," Alice Rizzuti offers a comprehensive, timely and compelling account of the ways in which food and the food industry exist as a key vector for significant harms and crimes. From food adulteration and mislabeling to outright fraud, Rizzuti reveals and contextualizes the intersections of food, crime and harm in the United Kingdom.

While food-and the harms or crimes associated with it-has received scant attention in criminologies green or otherwise, the nonhuman animals that play such essential roles in the global food industry, however, have captured green criminological attention for decades. "Wildlife Crime: A Crime of Hegemonic Masculinity?," Ragnhild Sollund's article in this issue, offers an example of the sort of critical scholarship that has come to characterize green criminology. Sollund reminds us that the animals we encounter in our lives are also worthy of care and consideration, while her critique of human violence against animals as an expression of hegemonic masculinity returns us to the social justice roots of green criminology so evident in those first moments of scholarship in the 1990s.

While Sollund looks squarely at the social world, green criminologists often find their inspiration in the tensions and contradictions created in and by law. Continuing the theme of nonhuman animals, James Gacek and Richard Jochelson, in "Animals as Something More Than Mere Property: Interweaving Green Criminology and Law," further probe the edges of human-animal relations by discussing and describing the development of laws governing human ownership and management of nonhuman animals, arguing that the studies of law and green criminology, when interwoven, "have the potential to reconstitute the animal as something more than mere property." Here, these authors remind us again of the value in fostering interdisciplinary approaches within green criminology and the ways that new areas of critical scholarship might emerge from those moments of cross-pollination.

Although green criminology finds it origins in the social justice perspectives articulated by Lynch (1990) and South $(1998,2014)$, it remains the case that procedural justice often dominates the conceptual landscape of the criminological imagination. James Heydon, in his article "Procedural 
Environmental Justice," expertly captures and describes the ways in which environmental justice perspectives might find in procedural systems the opportunity to democratize human-environment interactions. Through a case study of a controversial tree-felling program in Sheffield, England, Heydon makes strikingly clear the ways in which a social justice-oriented green criminology might find an unlikely ally or counterpart in more procedural forms of justice and justice-seeking.

If climate change represents one of the biggest issues regularly taken up by green criminologists, culture represents another. It is little wonder, after all, that "nature" and "culture" are the two words that so vexed even Raymond Williams, leading him to remark that while "culture is one of ... the most complicated words in the English language" (Williams 1973, p. 87), "nature is perhaps the most complex word in the language" (Williams 1973, p. 219). Green criminology, in a moment illustrative of the sort of disciplinary promiscuity and engagement we hope to encourage with this Special Issue, has started down a cultural path with the ongoing development of a green cultural criminology (see, e.g., Brisman and South 2013, 2014; Ferrell 2013; McClanahan 2014, 2019; Natali 2016). In the final article of this issue, "From Social Deviance to Art," Mark Palermo jumps with both feet into the cultural pool. By creating sculptural forms from found materials-what would, in most contexts, be considered waste materials-and then employing those art objects in an analysis of human patterns of consumption, Palermo offers a decidedly non-traditional but fascinating glimpse into the ties that bind art, culture, deviance, ecology, refuse and reuse.

We began this Editorial Introduction with a brief word on current conditions, and it seems appropriate to end this way, too. Writing, as we are, in the spring of 2020, it is difficult to imagine not addressing the global pandemic caused by the 2019 novel coronavirus that initially emerged in China and quickly swept across the planet. Here, we contend that this pandemic and the various social and economic challenges it has presented offer a unique opportunity to further understand ourselves as ecological beings. It is our hope that, in the wake of the pandemic and its chaos, we will find new ways to understand the ties that bind humans, animals and the ecological systems on which we all rely. One of the bright spots amidst the suffering of 2020 has so far been a new solidarity that has emerged, at least at the edges, which might contribute to making a more empathetic social world and a healthier planet for us all. We hope that by encouraging interdisciplinary connections and conversations, by continuing to foster and stimulate thoughtful scholarship into the natural and built worlds around us and by striving for justice, we might, as a discipline, play some role in the (re)building of a better Earth.

Conflicts of Interest: The authors declare no conflict of interest.

\section{References}

Bloomberg, Michael R., and Gina McCarthy. 2020. How Trump's EPA Is Making Covid-19 More Deadly. Bloomberg, May 4. Available online: https:/www.bloomberg.com/opinion/articles/2020-05-04/how-trump-s-epa-ismaking-covid-19-more-deadly (accessed on 25 September 2020).

Brisman, Avi, and Nigel South. 2013. A green-cultural criminology: An exploratory outline. Crime Media Culture 9 : 115-35. [CrossRef]

Brisman, Avi, and Nigel South. 2014. Green Cultural Criminology: Constructions of Environmental Harm, Consumerism, and Resistance to Ecocide. London: Routledge.

Browning, Dominique. 2020. An Earth Day We Can't Celebrate. The New York Times, April 22, p. A29, Published online as "Don't Celebrate Earth Day. Fight for It." on 21 April 2020. Available online: https://www.nytimes.com/2020/04/21/opinion/trump-epa-earth-day.html (accessed on 25 September 2020).

Editorial Board. 2020. A Decade after Deepwater Horizon. The New York Times, April 19. Available online: https://www.nytimes.com/2020/04/19/opinion/deepwater-horizon.html (accessed on 25 September 2020).

Ferrell, Jeff. 2013. Cultural criminology and green criminology. In Routledge International Handbook of Green Criminology. Edited by Nigel South and Avi Brisman. Abingdon: Routledge, pp. 349-64. 
Lockwood, D. 2020. Why Aren't We Excited About Earth Day Anymore? The New York Times, April 21. Available online: https://www.nytimes.com/2020/04/21/opinion/earth-day-2020.html (accessed on 25 September 2020).

Lynch, Michael J. 1990. The Greening of Criminology: A Perspective on the 1990s. Critical Criminologist 2: 3-4, 11-12.

McClanahan, Bill. 2014. Green and grey: Water justice, criminalization, and resistance. Critical Criminology: An International Journal 22: 403-18. [CrossRef]

McClanahan, Bill. 2019. Earth-world-planet: Rural ecologies of horror and dark green criminology. Theoretical Criminology. [CrossRef]

Natali, Lorenzo. 2016. A Visual Approach for Green Criminology: Exploring the Social Perception of Environmental Harm. London: Palgrave Macmillan.

Popovich, Nadja, Livia Albeck-Ripka, and Kendra Pierre-Louis. 2020. The Trump Administration Is Reversing Nearly 100 Environmental Rules. Here's the Full List. The New York Times, Updated May 6. Available online: https://www.nytimes.com/interactive/2020/climate/trump-environment-rollbacks.html (accessed on 25 September 2020).

South, Nigel. 1998. A Green Field for Criminology? A Proposal for a Perspective. Theoretical Criminology 2: 211-33. [CrossRef]

South, N. 2014. Green Criminology: Reflections, Connections, Horizons. International Journal for Crime, Justice and Social Democracy 3: 5-20. [CrossRef]

Tollefson, Jeff. 2020. Five Ways Trump Is Undermining Environmental Health. Nature 581: 17. [CrossRef] [PubMed]

Tuholske, Jack. 2017. What Lessons Does the US' 'Environmental Decade' Hold for China? Chinadialogue.net, August 11. Available online: https://chinadialogue.net/article/show/single/en/9975-What-lessons-does-theUS-Environmental-Decade-hold-for-China- (accessed on 25 September 2020).

Williams, Raymond. 1973. Keywords: A Vocabulary of Culture and Society. Oxford: Oxford University Press.

(C) 2020 by the authors. Licensee MDPI, Basel, Switzerland. This article is an open access article distributed under the terms and conditions of the Creative Commons Attribution (CC BY) license (http://creativecommons.org/licenses/by/4.0/). 